\title{
The Biosafety Regulatory Approach and Governance Mechanism of GM Crops in the Philippines
}

\author{
Leonardo N. Pasquito \\ College of Science and College of Governance and Public Policy, University of Makati \\ (email: kingleothesixth@gmail.com)
}

\begin{abstract}
This paper analyzes the government biosafety regulatory approach to genetically modified (GM) crops in the Philippines focusing on the interplay and politics of the different government agencies (DOST-DOH-DENR-DA-DILG) that comprises the National Biosafety Committee of the Philippines (NBCP) in terms of entry permit applications of multinational companies, field trials, environmental assessment, health impact assessment, local supervision and regulation, commercial release and market test, nutritional study, and GMO product labelling. The study examines the regulatory policies of the Philippine government including local ordinances which aimed to support or discourage agricultural biotechnology innovations in the Philippines. Further, the paper investigates how the NCBP regulates the stakeholders' debate on the risks and benefits of GMOs to the environment, human and animal health, and its impact on the food security program of the country. The study argues that the Philippine government is gradually losing its grip on the implementation of biosafety regulations and that invoking the precautionary principle, there is a need to resolve disputes in favor of the constitutional right to a balanced and healthful ecology of the people. The lack of dialogue and participatory public consultation to prevent clashing of interests on the conduct of field trials resulted in endless GMO war and debate. Thus, the study further noted that at present there is a looming deadlock on the debate of GMO between stakeholders which eventually is creating snail-pace agricultural biotechnology innovations and consequently stalling the food security program of the country.
\end{abstract}

\section{Keywords:}

biosafety regulations; genetically modified organism; GMO War; precautionary principle; agricultural biotechnology

\section{Introduction}

As defined by Mendoza et al (2009), Genetically Modified Organisms (GMO) refers to any living organism that possesses a novel combination of genetic material obtained through the use of modern biotechnology or as defined by the Cartagena Protocol on Biosafety. Genetic modification started in 1946 when scientist discovered that genetic materials is transferable 
between species. Since then, the first GM plants (tobacco and petunia) were created until China becomes the first country to commercialized GM crops. In 1994, the approval of the United States for the first GM crops (Flavr Savr tomato) fit for human consumption, many genetic modification follows such as Bt Talong, Bt Papaya, Bt Corn, Golden Rice and many other, making this period the current era for GM crops (Figure 1).

\section{Figure 1}

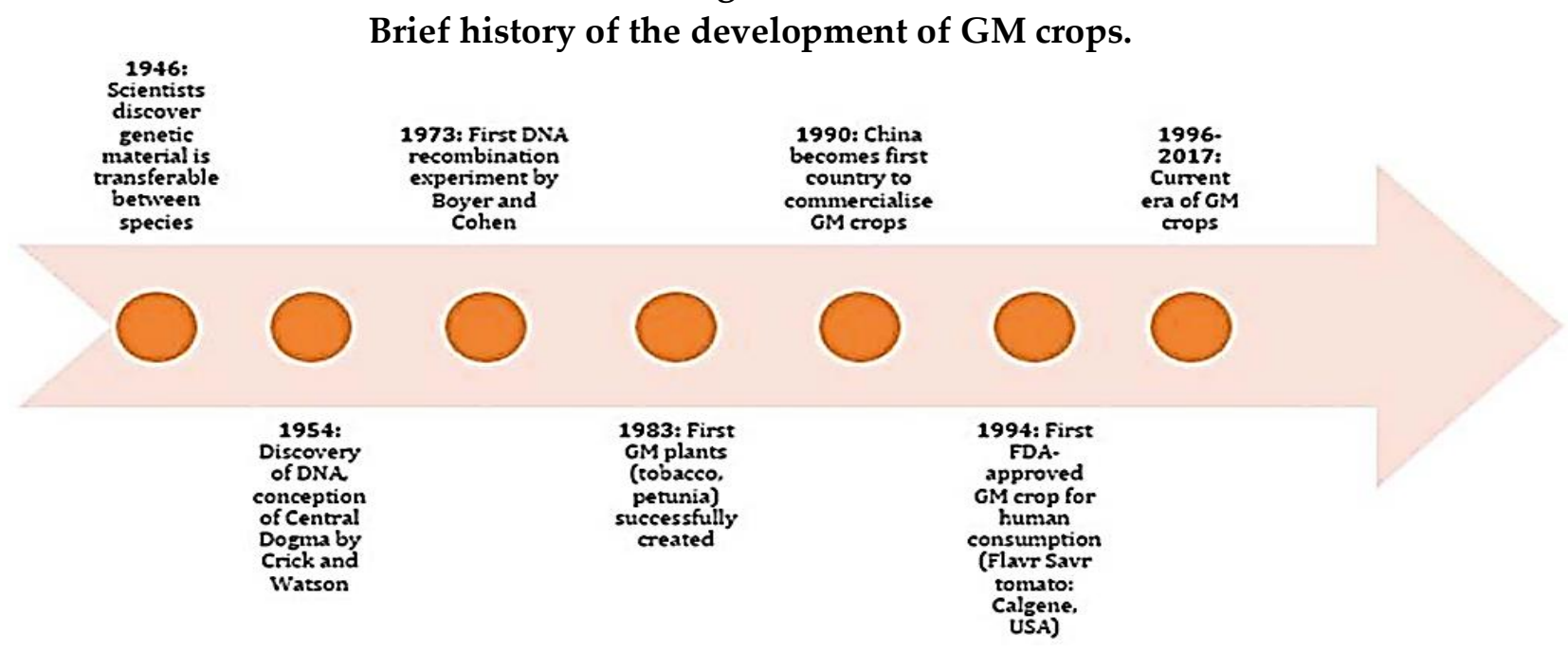

Source: Ruchir Raman (2017) DOI: 10.1080/21645698.2017.1413522

Among Asian countries, the Philippines ranked as the top grower of genetically modified (GM) crops in Southeast Asia and worldwide, the country ranked in 2016 as the 12th biggest GM crops producer globally (Perez, 2017). Since December 2002, there have been 70 approved GMO events, among which 62 GMOs were approved for food feed and processing (FFP) and 8 GMOs were approved for propagation (Arueloi, 2017).

Growing GM crops in the Philippines have faced many challenges. In 2001, anti-GMO groups destroyed an ongoing field trial on Bt corn in South Cotabato and in 2003, a petition was submitted to the provincial health officer of South Cotabato to investigate alleged health issues of some farmers prompting a Norwegian scientist to conduct research on the blood samples of the residents. The result was reported in various newspaper, which later turned out to be inconclusive (Peczon, 2009). Thereafter, bills were filed at Congress to ban the entry of GMO in the Philippines soil. Local Government Units (LGUs) likewise passed local ordinances to prevent entry of GMO in their locality. Like in any other countries, the biosafety regulations of GM technologies represents a challenge as this technology has been 
controversial which precipitated to opposing views and polarizing community into warring groups.

\section{Methodology}

This study utilizes meta-analysis of reviewed documents and published research paper related to GMO. Key government officials from UP-Los Baños, Department of Science and Technology (DOST), and Department of Agriculture (DA). The interviews helped identify experiences and challenges in the implementation of biosafety regulation. To validate the empirical data gathered and exhaust all possible suggestions and information relative the genetically modified crops, it conducted a focus group discussions (FGD) composed of academicians from selected universities, agriculturists, representatives from farmer sector, Public Administration students, researchers, consumers, and LGU representatives. After collecting all the data, appropriate statistical treatments were used such. A meta-analysis of related researchers were also conducted.

\section{Results and Discussion}

\section{The Biosafety Regulatory Agencies}

\section{The National Committee on Biosafety of the Philippines (NCBP)}

The NCBP is the lead body tasked to coordinate and harmonize inter-agency and multi-sectoral efforts to develop biosafety policies and set scientific, technical and procedural standards on actions by agencies and other sectors to, among others, promote biosafety in the Philippines. It is chaired by DOST Undersecretary for R \& D with the following members: 1 biological scientist, 1 environmental scientist, 1 physical scientist, 1 social scientist, 2 respected members of the community, and 1 representative each from the DA, DENR, DOH and DILG to be designated by the respective Heads Offices.

\section{National Biosafety Regulatory Agencies}

Under Section 4 of the Joint Department Circular No. 1, series of 2016, the national biosafety regulatory agencies are the Department of Agriculture (DA), the Department of Science and Technology (DOST), the Department of Environment and Natural 
Resources (DENR), the Department of Health (DOH), and the Department of the Interior and Local Government (DILG). The DA shall take the lead in addressing biosafety issues related to the country's agricultural productivity and food security. It shall also take the lead in evaluating and monitoring of regulated articles. The DOST shall take the lead in ensuring that the best available science is utilized and applied in adopting biosafety policies. It shall also take the lead in evaluating and monitoring regulated articles intended for contained use. The DENR shall ensure that environmental assessments are done and impacts identified in biosafety decisions. It shall also take the lead in evaluating and monitoring regulated articles intended for bioremediation, the improvement of forest genetic resources and wildlife genetic resources. The DOH shall formulate guidelines in assessing the health impacts. It shall also take the lead in evaluating and monitoring processed food derived from or containing GMOs. The DILG shall coordinate with the DA, DOST, DENR and DOH in overseeing the implementation of activities that are to be implemented in specific LGUs, particularly in relation to the conduct of public consultations, biosafety decisions, national application of quarantine functions, including biosafety assessments and evaluations.

Figure 2.

Organizational Structure of NCBP

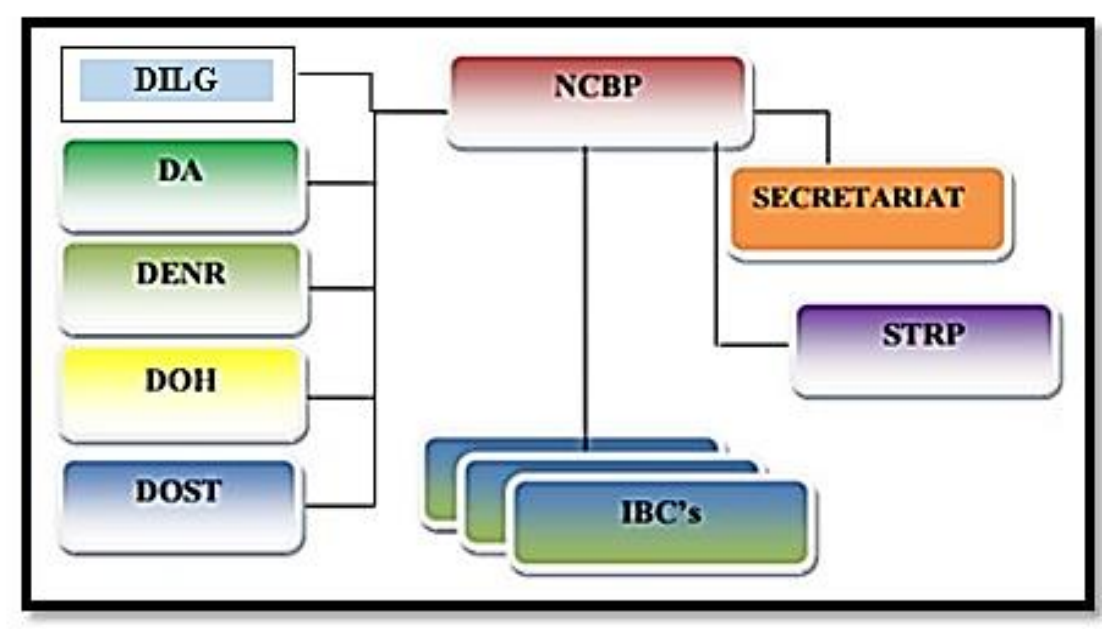

Source: Joint Department Circular No. 1, series of 2016.

On March 17, 2006, the Office of the President promulgated Executive Order No. 514 establishing the National Biosafety Framework (NBF), which is a combination of policy, legal, administrative and technical instruments developed to attain the 
objective of the Cartagena Protocol on Biosafety. The NBF can be considered as an expansion of the present National Committee on Biosafety of the Philippines (NCBP).

Figure 3.

The Composition of the DOST-IBC

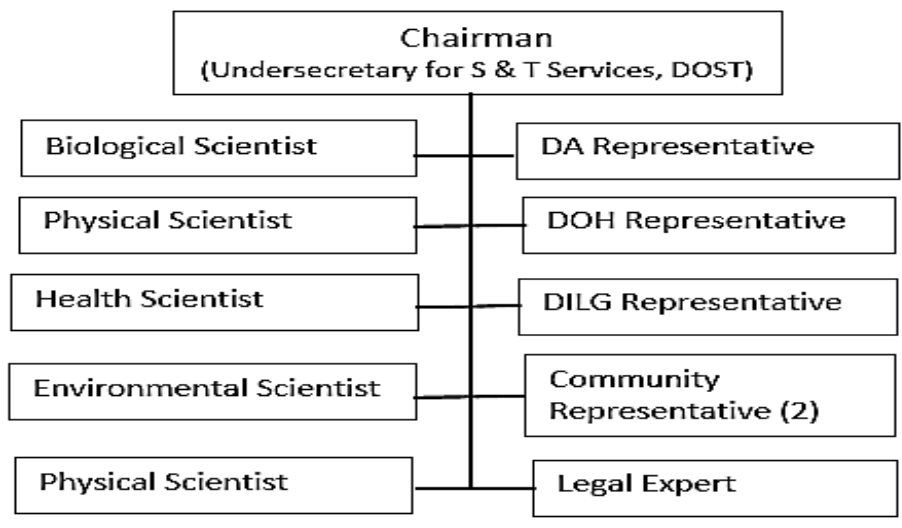

\section{The Institutional Biosafety Committee (IBC)}

All institutions engaged in genetic engineering or potentially hazardous biological and genetic engineering work are required to have an Institutional Biosafety Committee (IBC) which will evaluate and monitor the biosafety aspects of their biological research. It is composed of five (5) members with expertise in genetic engineering or pests, or who have the capability to assess the safety of research. At least two (2) members shall not be affiliated with the institution (apart from their membership with the IBC) and shall represent the interest of the surrounding community with respect to health and protection of the environment. Figure 3 shows hierarchy of members of the DOST-Biosafety Committee.

\section{Scientific and Technical Review Panel (STRP).}

The Scientific and Technical Review Panel is a panel created by the DA composed of a pool of non-DA scientists with expertise in the evaluation of the potential risks of regulated articles to the environment and human health. 
Table 1.

Biosafety Committees of National Agencies and their Evaluation Functions

Biosafety

Evaluation Function

Committee

DOST-BC Contained use and confined test of regulated articles.

DA-BC Field trial, commercial propagation, transboundary movement of regulated articles.

DENR-BC Environmental risks and impacts of regulated articles for field trial, commercial propagation, and direct use of living modified organisms.

DOH-BC Health impacts of regulated articles for field trial, commercial propagation, and direct use of living modified organisms.

Source: Section 5 of the Joint Department Circular No. 1, series of 2016.

\section{The Biosafety Regulatory Framework and Governance Mechanism}

Regulatory frameworks refers to the series of steps to ascertain if a regulated material will cause harm, injury and damage to humans, environment and to animals.

Figure 4

The GMO Governance Mechanism

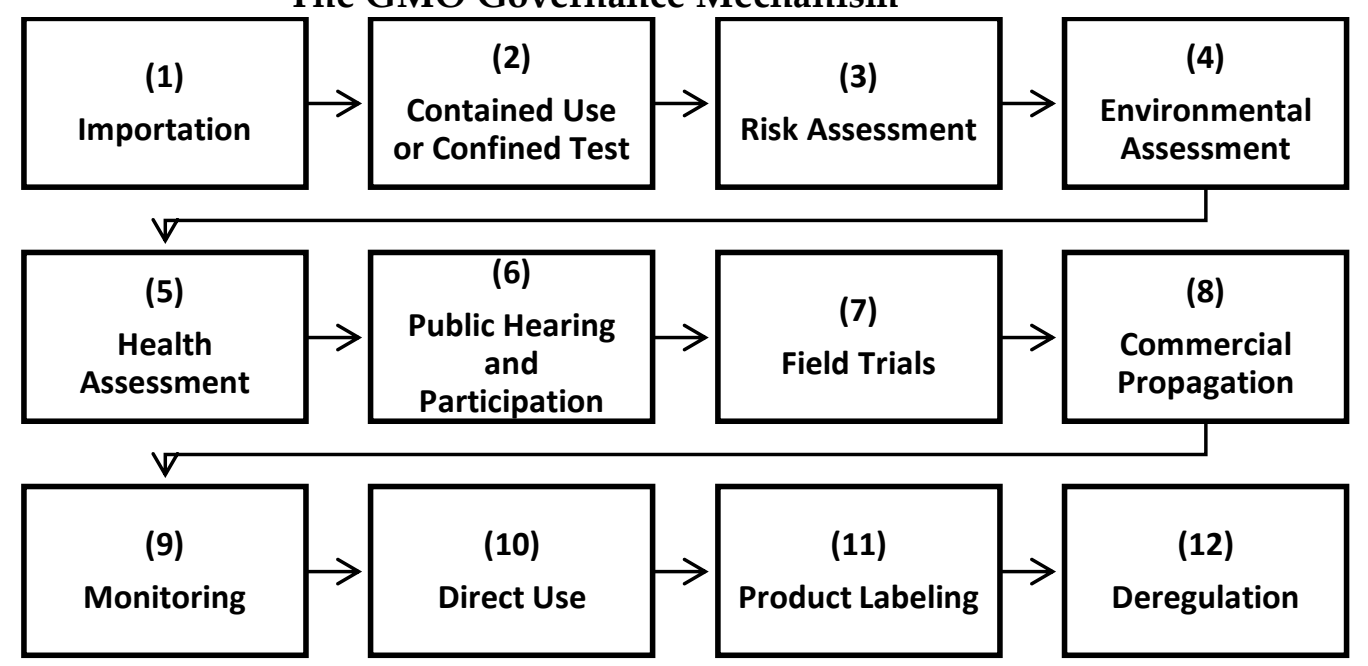

Source: Joint Circular No. 1 series of 2016

1. Importation. This is the bringing of GMO goods into the country for the purpose of contained use, confined test, field trial, commercial propagation, or direct use for food and feed or for processing. Importations requires a Sanitary and Phytosanitary Import Clearance (SPSIC) issued by the BPI and a documentation accompanying the regulated article indicating that it may contain GMO. Any applicant who desires to import a regulated article shall 
submit to the BPI Director three (3) copies of the Application Form for Importation for Contained Use or Confined Test plus a DOST-BC Letter of Endorsement (Figure 5).

Figure 5.

Biosafety Entry of GM crops

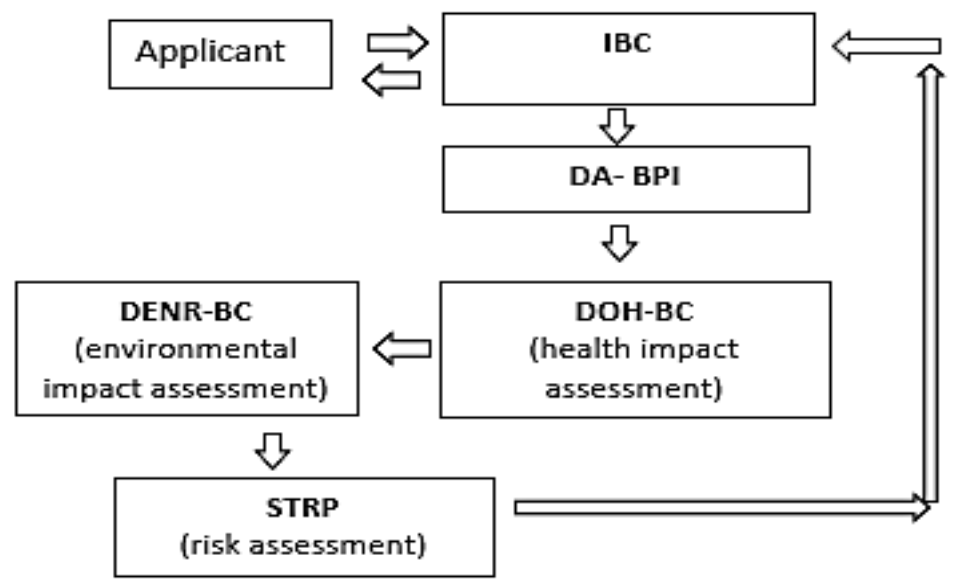

Within fifteen (15) days from acceptance of the application, the BPI Director shall approve the application if the importation of the regulated article does not pose greater risks to biodiversity and human health than its conventional counterpart; otherwise, the application shall be denied. Upon approval of the application, an SPSIC shall be issued in duplicate copies.

2. Contained Use and Confined Test. The contained use, including experiments inside laboratory, screen house, greenhouse, and glasshouse, and confined test of regulated articles shall be governed by the DOST-BC. The applicant shall submit application to IBC where it originates for evaluation. If approved, it will endorse the application to DOST-BC and refer it to individual expert(s) or to Scientific and Technical Review Panel (STRP) to evaluate potential adverse effects to human health and environment (Figure 6). 
Figure 6

Biosafety Regulation of GM crops for Contained Use or Test

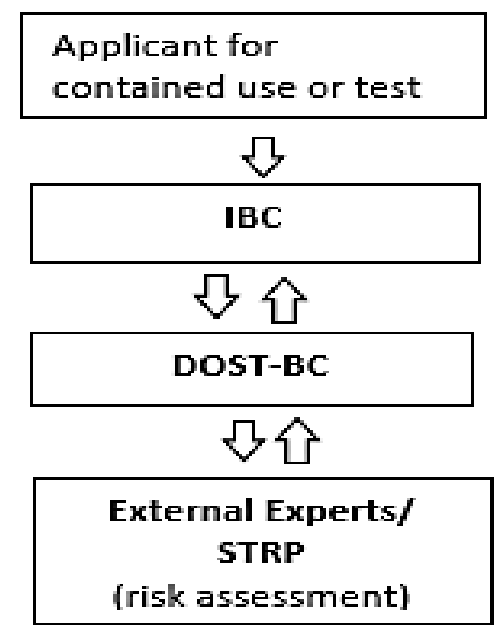

3. Risk Assessment. This refers to the evaluation conducted by IBC to determine if contained use, confined test or field trial of the regulated article does not pose greater risks to biodiversity, human and animal health. The STRP shall review the risk assessment conducted by the IBC and make its report and recommendation to the BPI.

4. Environmental Assessment. This refers to Environmental Impact Assessment (EIA) and Environmental Risk Assessment (ERA). The EIA is a process that involves predicting and evaluating the likely impacts of a project on the environment during construction, commissioning, operation and abandonment while the ERA refers the conduct of identifying and evaluating the potential adverse effects of regulated articles on the conservation and sustainable use of biological diversity in the likely potential receiving environment. The IBC conducts risk assessment while the DENR-BC assess the environmental impact of the project and make its recommendations to the BPI.

5. Health assessment. This covers health impact assessment (HIA) and the health risk assessments (HRA). The HIA is an assessment of the potential health effects on a population while the HRA is an estimate of the risk to a given target population following exposure to a particular agent. The $\mathrm{DOH}-\mathrm{BC}$ conducts HIA and HRA and make recommendations to the BPI. 
6. Public Hearing and Participation. Public hearing refers to the face-to-face meeting with stakeholders for information and comments while public participation refers to the promotion and conduct of public awareness and accountable participation to all stages of the biosafety decision making process.

7. Field trials. This is the intentional introduction into the environment of a regulated article that passed the contained use and confined test, for purposes of research and development. Field trials need a Biosafety Permit for Field and applicants are required to invite the public to give comments on the proposed activity. In this regard, the Public Information Sheet (PIS) must be posted for at least three (3) weeks in three (3) conspicuous places where the test site is to be conducted, and must also be published in a newspaper of general circulation where the test site is located. All comments shall be collated NCBP, forwarded to the concerned IBC, and relayed to the applicant for appropriate response. After the field trial, the applicant is required to submit a Completion Report (CR) to the IBC ninety within (90) days after its completion (Figure 7).

\section{Figure 7.}

Biosafety Regulation for Field Trial of Approved Applications

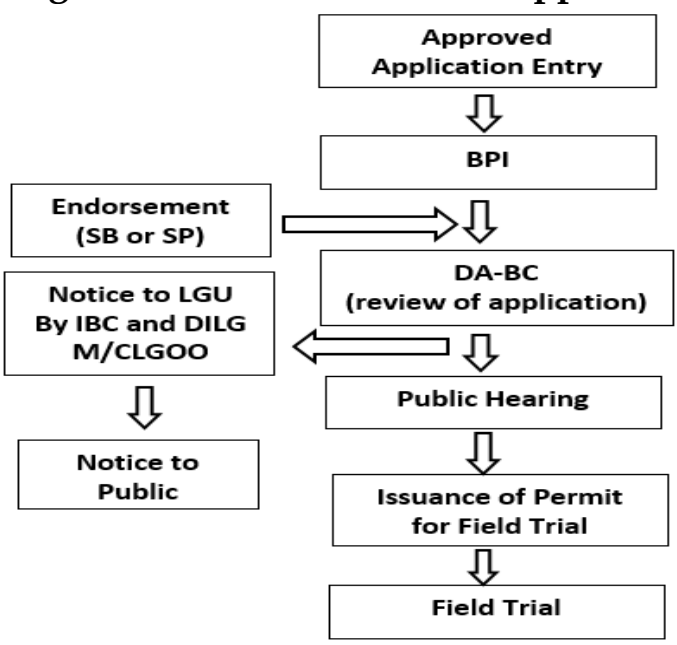

8. Commercial Propagation. This refers to the introduction into the market of a regulated article for consumption by humans or animals. This requires a Biosafety Permit for Commercial Propagation. Biosafety Permit for Commercial Propagation shall be valid for a period of not more than five (5) years, unless sooner revoked (Figure 8). 
Figure 8.

Biosafety Regulation for Commercial Propagation

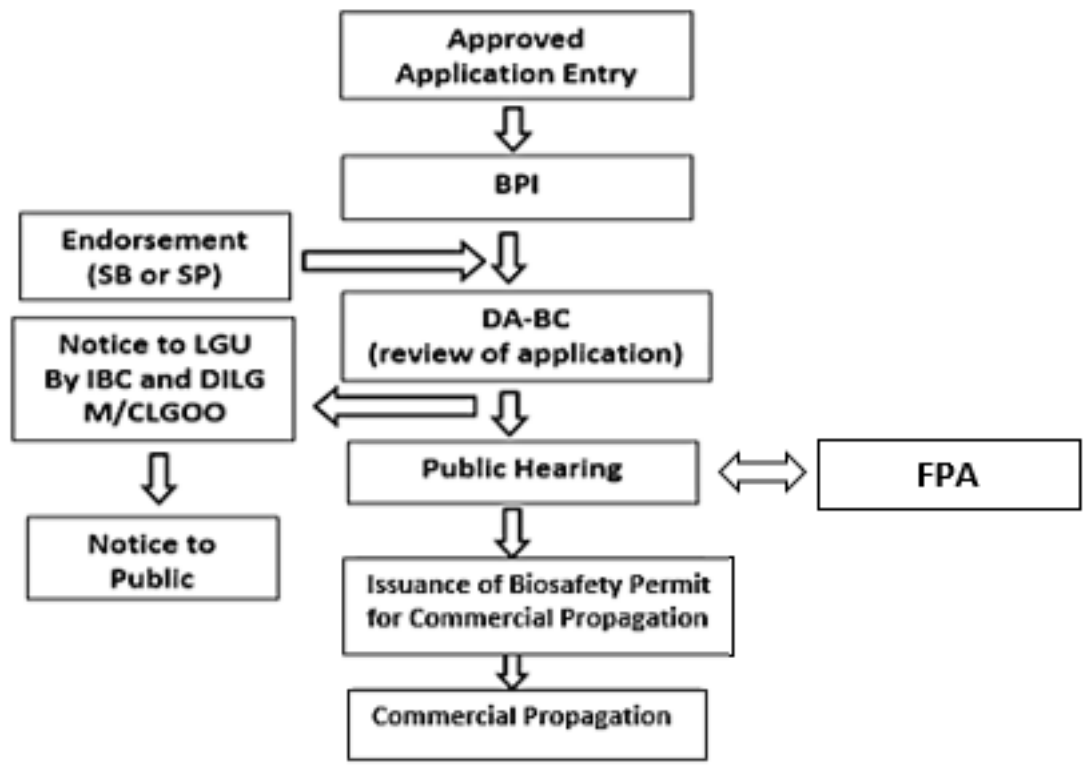

9. Monitoring. The field trial and commercial propagation of the regulated article shall be monitored by the BPI, DENR, DOH and reports should be submitted to the DA-BC for posting in the NCBP and BPI website. The DILG shall coordinate with the DA, DOST, DENR and DOH in overseeing the implementation of activities in specific LGUs, such as public consultations, biosafety decisions, quarantine, biosafety assessments and evaluations.

10. Direct Use. This refers to use of regulated article, whether imported or developed domestically as food and feed, or for processing. This requires a Biosafety Permit for Direct Use to be issued by the BPI (Figure 9). 
Figure 9.

Biosafety Regulation for Direct Use

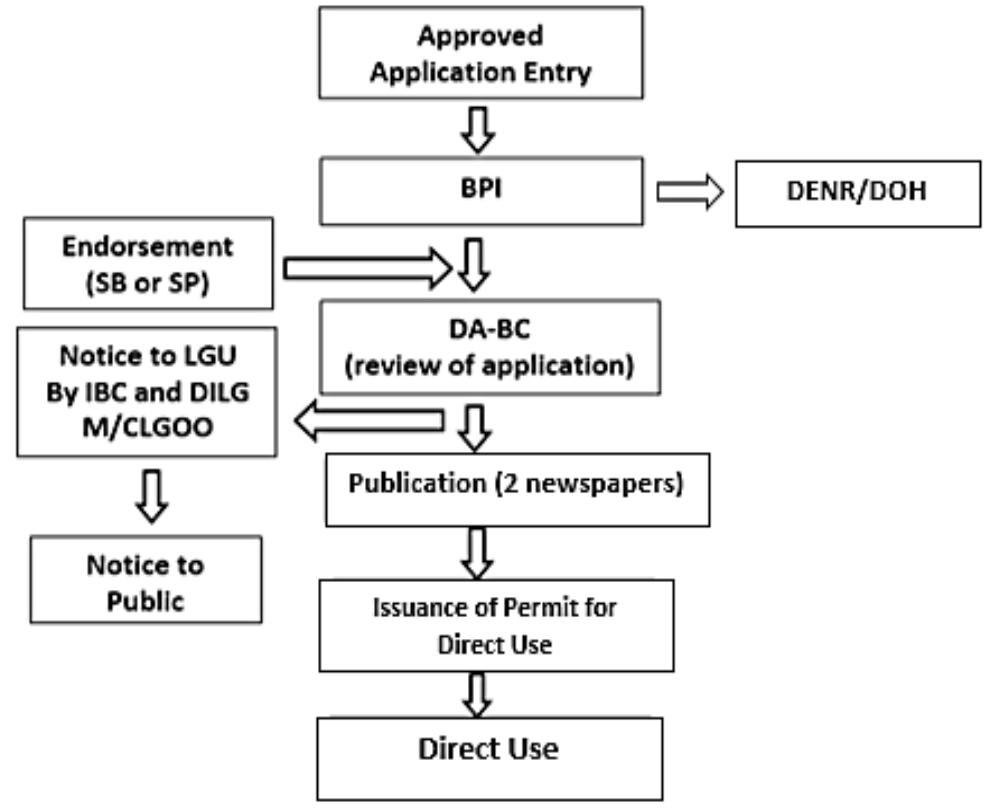

11. Product labelling. This is an act of listing or describing the ingredients, quality, and nutritional value of a GM products for food safety and nutrition. Labelling of GM foods helps consumers make an informed choice about the food they buy.

12. Deregulation. This is the removal of the regulated article from the coverage of NCBP biosafety regulation when as assessed by the BPI, it will not pose greater risks to human and animal health, and to the biodiversity. This can be done even before the expiration of Biosafety Permits.

\section{National Biosafety Policies and Local Ordinances}

Many national guidelines or rules have come in place to regulate the GMO crops and these are:

Executive Order No. 514. This Order established the National Biosafety Framework (NBSF) which formally identified the national competent authorities in charge of biosafety regulation of modern biotech activities for the purposes of complying with the provision of the Cartagena Protocol on Biosafety. Under this Order, each concerned department will have its own biosafety committee. This Order specifically identified the DOST to be responsible agency for regulating GMO experiments and the DA Bureau Plant Industry for regulating field testing and commercialization of biotech crops. 
DOST-DA-DENR-DOH-DILG Joint Department Circular No. 1, series of 2016. This Joint

Circular sets out the Rules and Regulations for the Research and Development, Handling and Use, Transboundary Movement, Release into the Environment, and Management of Genetically-Modified Plant and Plant Products Derived from the Use of Modern Biotechnology

Until today, there is no specific laws enacted to regulate the biosafety of GMOs. However, there are many pending bills filed at the House of Representatives and Senate of the Philippines. The highest number of bills are those that requires labelling of GM food (HB 04192, HB 04352, HB 03810, HB 03686, and HB 02780). There are also bills which intends to ban of importation of GMO (HB 03057), and those that prohibits the use of products containing GMO (HB 05699, and HB 02719). All of these bill are either referred to a particular committee or deliberated and abandoned after (Table 1).

Table 1

Pending GMO Bills at the House of Representatives

\begin{tabular}{|c|c|c|c|}
\hline Short Title & House Bill (Year filed) & $\begin{array}{l}\text { Number of } \\
\text { Bills }\end{array}$ & Status \\
\hline $\begin{array}{l}\text { Mandatory Labeling of Food } \\
\text { Containing GMO }\end{array}$ & $\begin{array}{l}\text { HB } 02780 \text { (2019), HB } 03686(2016) \\
\text { HB } 03810 \text { (2016), HB } 04352 \text { (2014) } \\
\text { HB } 04192 \text { (2014) }\end{array}$ & 5 & Pending \\
\hline $\begin{array}{l}\text { GMO-free Agricultural Act } \\
\text { GMO Ban Act }\end{array}$ & $\begin{array}{l}\text { HB } 02709 \text { (2016), HB } 05699 \text { (2015) } \\
\text { HB } 03057 \text { (2010) }\end{array}$ & $\begin{array}{l}2 \\
1\end{array}$ & $\begin{array}{l}\text { Pending } \\
\text { Pending }\end{array}$ \\
\hline
\end{tabular}

Source: $h$ ttp://www.congress.gov.ph/legisdocs/?v=billsresults $\# 18$

At the Senate of the Philippines, most of the pending biosafety bills pertains to mandatory labeling of food containing GMO (SB 2338, SB 546, SB 2079, SB 1473, SB 797, SB 2073, SB 768, SB 546, SB 1763, SB1702, SB 604, SB 120), followed by GMO Restriction Act which prohibits the release or introduction of genetically-modified organisms into the environment SB 1680 (2013), 644, SB 374, and SB 1775), and the GMO Registry which aims to establish a registry (SB 1209, SB 1676, and SB 2615). There is one bill on GMO Liability Act which intends to provide protections for farmers harmed economically by this biotechnology (SB 3231) and GMO Ban Act which prohibits the importation of GMO crops and products (SB 28). All of these bills are pending at present. Since then, no Senate Bill on GMO has been filed during the $16^{\text {th }}$ Congress (July 2013 - 2016) and during the 17th Congress (July 2016 - 2019). 
Table 2

Pending GMO Bills Filed at the Senate of the Philippines

\begin{tabular}{llcc}
\hline \multicolumn{1}{c}{ Short Title } & \multicolumn{1}{c}{ Senate Bill (Year Filed) } & $\begin{array}{c}\text { Number } \\
\text { of Bills }\end{array}$ & \multicolumn{1}{c}{ Status } \\
\hline GM Food Labeling Act & SB 2338 (2014), SB 546 (2013), SB 2079 (2010), & 13 & Pending \\
& SB 1473 (2010), SB 797 (2010), SB 2073 (2008), & & \\
& SB 768 (2007), SB 546 (2007), SB 1763 (2004), & & \\
& SB1702 (2004), SB 604 (2004), SB 120 (2004), & & \\
& and SB 52 (2004) & 4 & Pending \\
GMO Restriction Act & SB 1680 (2013), 644 (2010), SB 374 (2007), & & \\
GMO Registry & and SB 1775 (2004) & 3 & Pending \\
GMO Liability Act & SB 1209 (2013), SB 1676 (2010), and SB 2615 (2008) & 1 & Pending \\
GMO Ban Act & SB 3231 (2009) & 1 & Pending \\
\hline
\end{tabular}

Source: https://www.senate.gov.ph/lis/leg_sys.asp $x$ ?congress=13Etype $=$ billE $p=1$

\section{Local Ordinances on GM Crops Biosafety}

There are local government units (LGUs) which enacted ordinances to ban the entry of GM crops in their locality. For example, City of Bohol enacted Resolution 2003-235 which was passed by the Sanggunian Panglungsod (SP) declaring the province free of GMO. Later, Sanggunian Panlalawigan passed Provincial Ordinance 2003-010 which enumerates the conditions against the entry GMO into the province. With this ordinance, the province of Bohol becomes the first GMO Free Island in the Philippines.

In 2009, the City Government pushed for the total ban of GMO by passing Organic Agriculture Ordinance to ban GMO in the city. In 2010, then Mayor Sara Duterte-Carpio ordered the uprooting of Bt eggplant being field-tested at the UP Mindanao as the proponents allegedly failed to conduct consultations with the city and other concerned sectors. The City later, in 2011, passed a Resolution to ban field testing of Bt Eggplant (Carillo and Padillo, 2015).

As part of the Organic Haven Islands of Mindoro, Marinduque, Romblon and Palawan (MIMAROPA), the both provinces of Mindoro Oriental and Marinduque have a Provincial Environmental Code and Administrative Order also banning the entry of GMOs in their areas. (Espina, 2006)

In 2005, Negros Occidental and Negros Oriental signed a memorandum of agreement (MOA) to become the Organic Island of the Philippines (Espina, 2006). Realizing the MOA, the Negros Occidental Provincial Board passed Provincial Ordinance No. 007 Series of 2007 declaring a ban of GMOs from entering the province. On the other hand, the Negros Oriental Provincial Board passed Provincial Ordinance No. 7 Series of 2010, declaring a ban on GMOs 
to make the island of Negros the Organic Food Bowl of Asia and maintaining Negros as the training center for farmers from all around the Philippines. This ordinance was tested when a shipment of GMO corn worth P18 million was rejected at Bacolod City port (Novenario, 2018).

North Cotabato, currently the biggest exporter of brown and red organic rice in the country has also banned GM Rice to protect the welfare of the farmers, as well as the health of their constituents. It passed the SP Ordinance 2015-14-005 which bans all GM varieties of rice in its market. This makes North Cotabato as second province in the country to ban the GMO next to Misamis Oriental (Philippine News Agency, 2015).

There are also other provinces and municipalities in the country which have GMO Ban Ordinances such as the Municipalities of Teresa, Cabangcalan, Dumingag, and Sto. Niño. Other provinces and municipalities, although having no ordinance on the direct ban on GMO have enacted Organic Agriculture Ordinance instead, such as the provinces of Mindoro Oriental, Quezon, Negros Occidental, Negros Oriental, Bukidnon, Davao del Norte, North Cotabato, South Cotabato, the municipalities of Dumingag, Sto. Niño, Teresa, Cabangcalan, and the cities of Bais and Bayawan (Arueloi, 2017).

\section{Regulating the GMO War}

The debates over GM foods focus mostly on uncertainties concerning the potential adverse effects of GM foods on human health and environment. The debates on the GMO can be attributed to the the difficulty of the scientific community in explaining clearly to the public how genetic modification is done, improper dissemination on the GM foods, and inadequacy of evaluation studies of the GM foods (Baulcombe et al, 2014). These contributed to GMO endless debates and GMO war.

On May 2012, the Court of Appeals blocked the field testing of Bt eggplant conducted by pro-GMO groups of DA, DENR, UP Los Baños and UP Mindanao because there was no final scientific findings yet as to its health effects, it endanger the health of the people and may destroy the environment and. It upholds the precautionary principle which states that "when human activities may lead to threats of serious and irreversible damage to the environment that is scientifically plausible but uncertain, actions shall be taken to avoid or diminish the threat." The petition was filed by Greenpeace and a certain farmers' group called MASIPAG.

In 2015, three years after the CA blocked the field testing of Bt talong , the Supreme Court issued a Writ of Kalikasan favoring the Greenpeace Southeast Asia. A Writ of Kalikasan is 
a legal remedy under Philippine law that provides protection against environmental damage of such magnitude that it threatens life, health, or property of inhabitants. This Writ was hailed as one of the major victories of Filipino farmers. The SC based its decision on the premise that many countries in Europe are rejecting GE crops and that the country may also do the same until a new regulatory order is issued by the government.

Calling the decision unacceptable, pro-GMO groups such as Crop Life Philippines, Inc (CLPI), Environmental Management Bureau (EMB), International Service for the Acquisition of Agri-Biotech Applications Inc (ISAAAI) and UP Los Baños, filed a motion for reconsideration (MR) together with a new regulatory order as advised. Then, in what is called as the first in Asia, the Supreme Court reversed its 2015 decision and finally allows field testing of GM crops.

Figure 10.

Benefits of GM Crop Technology

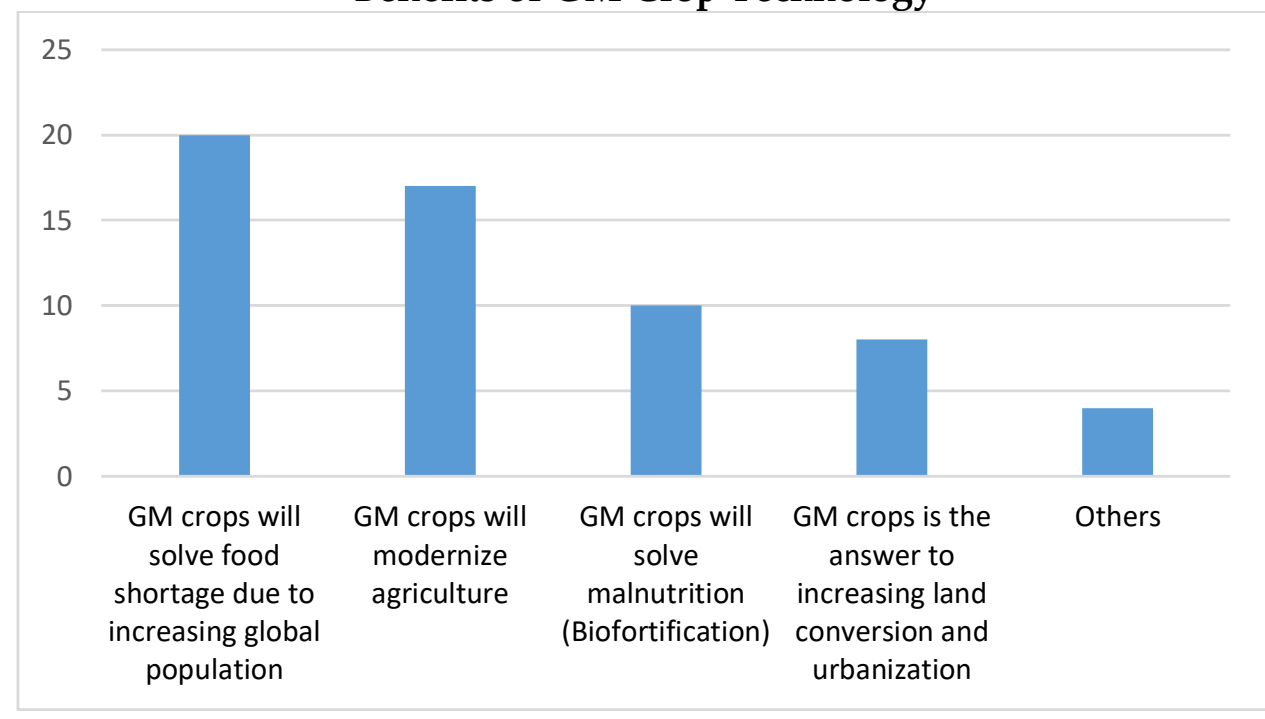

An interview was conducted to key government officials, academicians and other stakeholders on the benefits of GM technology. Accordingly, the government is promoting GM crops because it will solve food shortage due to increasing global population which is projected by the United Nations (2015) to reach from 7.7 billion at present to 9.7 billion by 2050. Likewise arable land for food production per person is estimated to decrease from the current 0.242 ha to 0.18 ha by 2050 due to massive urbanization (Alexandratos, 2012). Another reason is that GM technology is an important tool for modernization and global competitiveness of agriculture in the Philippines to provide farmers with higher yields. Moreover, this technology is perceived to cure malnutrition and vitamin deficiency citing the 
biofortification of Golden Rice. There are also those who claimed that GM crops will improve socio-economic profile of farmers and will pave way for modern farming method. Figure 10 shows frequency distribution of key informant's response to the reasons why government is promoting GM technology.

On the other hand, anti-GMO groups have countered that the government efforts in promoting GM crops is not the real solution to eradicate food insecurity. Responses from a survey conducted to anti-GMO groups, academicians and consumers pointed revealed that many respondents identifies GM technology as a danger to the health of the consumers because there is no scientific consensus yet on how safe GM crops to humans creating uncontained fear and uncertainty. The study of Bawa et al (2013) and Zhang et al (2016) identified three (3) major health risks associated with GM foods as toxicity, allergenicity and genetic hazards possibly due to expressed proteins of inserted gene, possible disruption of natural genes and activation for toxin production. Further, some respondents said that GM technology is an anti-God, an act of "playing God" with living things. Some respondents also countered that farming using GM seeds is ineffective method because requires special and controlled environment unlike the organic method. Lastly, few respondents claimed that GM crops will contaminate native crops and may cause genetic pollution to native gene pool and disrupt food web. They opined that GM if crops are exposed to nature and cause harm, the government does not have specific mechanism to recall mitigate its unforeseen impact to the ecosystem.

Figure 11.

Risks and Dangers of GM Crop Technology

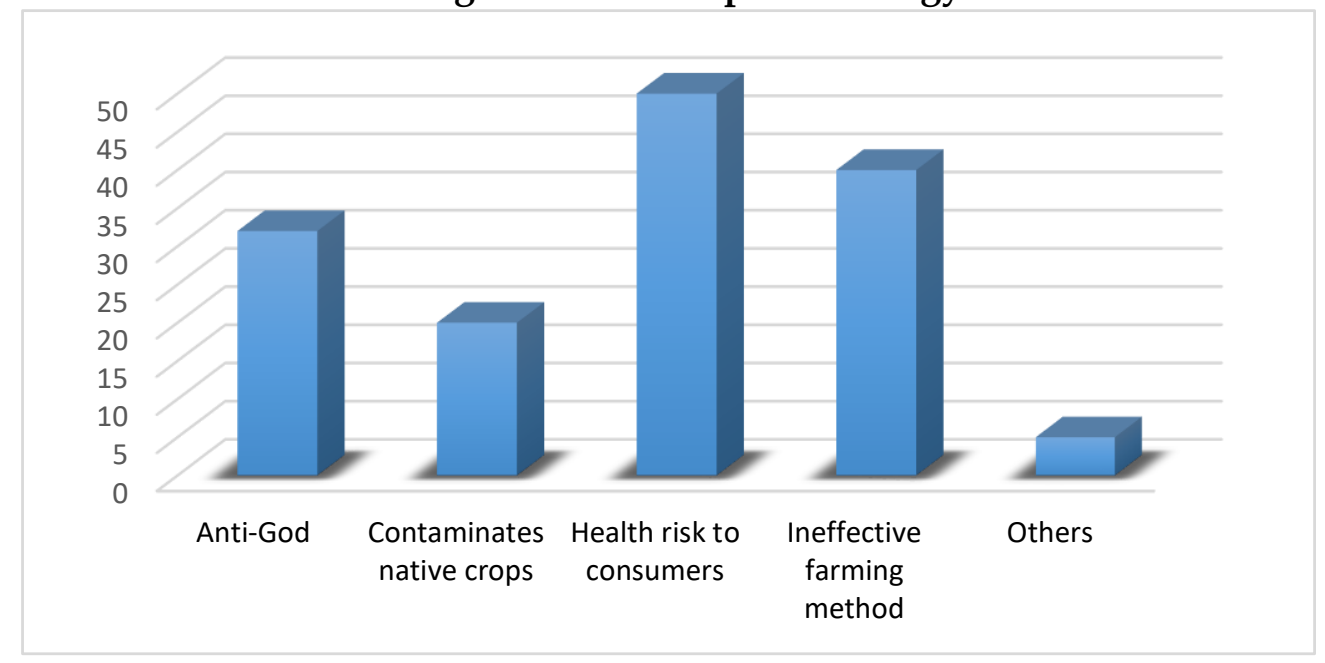


Aside from these, few respondent stated that promoting food security does not depend on GM crops alone but in the innovative farming system, provision for modern farming infrastructure, and proper agrarian reform to address landlessness (Figure 11).

\section{Institutional Experiences and Program Consequences}

In 1990, after the Master Science Plan was drawn by DOST, then President Corazon Aquino created the National Committee on Biosafety of the Philippines (NCBP) through an EO 430 to implement and oversee biosafety compliance. Seven years after, President Fidel Ramos approved the Five-Year Crop Biotechnology Program involving coconut, corn, mango, banana, and papaya. This was followed by the enactment of the Agriculture and Fisheries Modernization Act (AFMA) which stipulates that biotechnology should be part of the agricultural R\&D budget. Following the approval of the Five-Year Crop Biotechnology Program, the NCBP conducted the first field tests of Bt corn to test its efficacy against the Asiatic Corn Borer (ACB). This was conducted from December 1999 to March 2000 in Ilocos Norte, Pangasinan, Isabela, Bicol Region, Bukidnon, Misamis Oriental, South Cotabato, Sultan Kudarat and other provinces in Mindanao. The field test exposed NCBP members to engage debate with anti-GMO, attend Congress Session to explain GM technology, and be implicated as respondents in a suit at the Supreme Court. (Mendoza et al, 2009).

In year 2000, Philippines has adopted the Cartagena Protocol on Biosafety which mandates GM crop importers to declare GM goods which before the adoption was based purely on voluntary disclosure (Mendoza et al, 2009). Two years after, the DA issued AO No. 8 which designate functions to evaluate field tests and commercial propagation of GM crops to Bureau of Plant Industry (BPI), and redefined NCBP function to focus on research and development (Mendoza et al, 2009). In 2006, EO No. 514 established the National Biosafety Framework (NBF) which formally identified national competent authorities in charge of biosafety regulation, mandates the constitution of biosafety committee per agency, mandates DOST to regulate contained use experiments while DA BPI to regulate field testing and commercialization (Mendoza et al, 2009). It also stipulated standards for decision making such as the Precaution Principle, Principle of Risk Assessment, Principle of Monitoring and Enforcement, and the Principle of Public Awareness, Education and Public Participation. 
In 2001, then President Gloria Macapagal-Arroyo articulated in a policy statement regarding the safe and responsible use of modern biotechnology as one of the means to achieve and sustain food security (Panopio and Navarro, 2011). Thus, having strong political support by the government, the Philippines in 2002 approved the commercialization Bt corn MON 810 making the country as the first and only Asian country to grow a major biotech crop. These events however have elicited controversy where anti-GMO urged the public not to patronize GMOs. This led to hunger strikes, stakeholder protests, use of visual tactics showing a devil holding GM products, and the use of catchphrases for GMO in media as demon seeds, super weeds, tinkering with nature. While scientists were promoting GMO adoption, anti-biotech used print, radio, and television to sow threat to the public that the technology causes baldness, infertility, and homosexuality. The religious sector also conducted a rally raising issues that genetic engineering is unethical and anti-God and GM foods are therefore abnormal or mutant food. This was conducted amidst a controversy that GM corn caused an adverse effect on the health of B'laan tribe of the province. This also prompted local government units (LGUs) to enact ordinances to ban field trials (Panopio and Navarro, 2011).

In May 2003, members of the Southeast Asian Regional Institute for Community Education (SEARICE), Philippine Greens, and Greenpeace protested against the commercial release of Bt corn by holding a month long hunger strike in front of the DA office. On the same year, 200 farmers from Kilusan Magbubukid sa Pilipinas, MASIPAG, Bagong Alyansang Makabayan in Mindanao protested at the Central Mindanao University against the Bt corn field testing. They conducted massive information drive on the ill effects of GMOs. In Isabela province, about 300 church leaders staged a lightning rally in front of Monsanto Marketing Office in Cauayan City, conducted a noise barrage to oppose ongoing Bt corn field tests, and burned a giant paper mâché bug representing Monsanto. A few years later, 150 farmers and priests attended the Peasants-Clergy Conference in Jaro, Iloilo to oppose all GMO programs.

In August 2003, a petition was submitted to the provincial health officer of South Cotobato and to the media regarding health concerns of some members of B'laan tribe of Barangay Landan, Polomolok. Blood samples of 38 farmers were obtained by Dr. Terje Traavik, scientific director of the Norwegian Institute of Gene Ecology and presented his findings in February 2004 at the 7th meeting of the Conference of Parties of the Convention 
on Biological Diversity in Bangkok, Thailand. To validate these allegations, medical experts from the UP Manila conducted series of dialogue with city council and provincial health officers on the technical soundness of Dr. Traavik's study. With no full report presented, South Cotabato health officials later clarified that the respiratory infection of the farmers was not the effect of GM foods (Peczon, 2009). After this incident, several bills were filed in Congress seeking to limit the introduction of GM crops and investigate alleged corporate influence over the government approval process for Bt corn (PANNA, 2003). Anti-GMO groups also lobbied to persuade local officials to enact ordinances banning GM crops. With this, in August 2005, the Governors of Negros Occidental and Negros Oriental signed a Memorandum of Agreement on the establishment of the "Negros Organic Island." In effect, the Negros Occidental Provincial Board passed Ordinance No. 007 Series of 2007 declaring a ban on living GMOs from entering the province. Anti-GMO advocates such as Greenpeace dressed as chickens circulated a petition urging the Sangguniang Panlalawigan to implement rules and regulations towards an Organic Negros Island. The petition was signed by farmers, students, business owners, workers, consumers, and other citizens of Negros. (Panopio and Navarro, 2011).

After the incident, from 2005 to 2011, there were many events that transpired. In 2005, commercial planting of corn tolerant to herbicide Glyphosate was approved by DA. The Senate also ratified the Cartagena Protocol on Biosafety (CPB) and the National Biotechnology Week (NBW) was launched through Presidential Proclamation No. 1414. It also established the National Biosafety Clearinghouse known as the BCH Pilipinas. The field trial of Bt Cotton was conducted by Philippine Fiber Development Administration (PFIDA) and the field trials of Bt talong and Biotech Papaya was conducted by Institute of Plant Breeding of the University of the Philippines at Los Baños (IPB-UPLB) (Peczon, 2009; ISAAA brief, 2016). The Philippine government likewise established the Biotechnology for Life Media and Advocacy Resource Center (BMARC) to provide an extensive public information campaign on biotechnology. A bi-monthly Biolife Magazine was also created to feature recent developments in Philippine biotechnology as well as answers to issues (Panopio and Lapitan, 2009). They government, spearheaded by J. Burgos Media Services, also conducted promotion activities by offering course development and capability building programs to educate the local chief executives 
and concerned agricultural officers of the vast potential and benefits of modern biotechnology (Fernandez et al., 2007).

In October 5, 2006, the Cartagena Biosafety Protocol was ratified by Senate and came into force on January 3, 2007. The Protocol aims to ensure adequate level of protection in the safe transfer, handling, and use of living modified organisms (LMOs) through Prior Informed Consent (PIC) and the precautionary approach (PA). Under PIC, the exporting State is mandated to inform importing State regarding the its hazards, while under PA, the importing States may decline GMOs on grounds of scientific uncertainty .

In 2012, the Institute of Plant Breeding of the University of the Philippines at Los Baños (IPB-UPLB) conducted Field trials of Bt Talong and Biotech Papaya (ISAAA brief, 2016). Prior to this, studies were conducted on the potential costs and benefits of Bt eggplant commercialization after field trials in the province of Pangasinan and Camarines Sur. This was initiated because eggplant farmers suffer significant yield losses annually due to the Eggplant Fruit and Shoot Borer (FSB) (ISAAA, 2014). When anti-GMO advocates found out that field trials was being conducted without their knowledge, a lawsuit was filed in 2012 to stop its commercialization (ISAAA Brief, 2016). The following year, the Court of Appeals (CA) issued a ruling saying that the introduction of Bt talong into the Philippines poses a grave and present danger to the constitutional right to a balanced ecology and therefore destroys the balance of biodiversity (CA Decision, 2013; Dubock, 2014). The CA also uphold the precautionary principle which states that "when human activities may lead to threats of serious and irreversible damage to the environment that is scientifically plausible but uncertain, actions shall be taken to avoid or diminish the threat." It also noted that scientists have no consensus on the safety of Bt talong and that these divergent views reflect the continuing international debate on GMOs.

In 2013, PhilRice and IRRI discreetly carried out confined field test on Golden Rice. When anti-GMO learned this, 400 protesters trooped to the office of the Department of Agriculture's Regional Office in Pili, Camarines Sur and destroyed an 800 square meter field trial plot of Golden Rice (Berlekamp, 2013). According to the farmers, the direct action was to prevent contamination of their precious traditional and farmer-bred varieties (GRAIN et al., 2018). 
On December 2015, the Supreme Court of the Philippines issued a Writ of Kalikasan to permanently ban field trials of Bt talong as filed by Greenpeace Southeast Asia et al. It also invalidates DA AO No. 8 series of 2002 due to lack of meaningful public participation, the non-implementation of the Environmental Impact Statement and the absence of standards for risk assessment. It noted that the Order did not provide enough safety guarantee for the environment and the health of people. With this SC decision, the government has cited serious implications. First, stopping the Bt eggplant field trials basically infringes on the academic freedom of the UP Los Baños researchers. Second, on-going field trials for drought tolerant corn will be discontinued even if it was intended for drought due to climate change. Third, permits for GM corn currently planted by more than 400,000 farmers will not be renewed. Fourth, the livestock industry which import million metric tons of soybean and GM corn for animal feeds will be stopped. Fifth, importation of GM soybean, GM canola and GM corn will stop and importers have no choice but to buy non-GMO goods leading to increases in food prices of food products using GM ingredients such as hotdogs, baby food, taho, soy sauce and many more. Sixth, the health sector will suffer because it will stop importing GMO health product such as Hepatitis B vaccine (Crismundo, 2015).

In 2016, complying with the declaration of the SC that contained use, field testing, propagation and commercialization, and importation of genetically modified organisms is temporarily enjoined until a new administrative order is promulgated, the government created a Technical Working Group that drafted the new rules and regulations of modern biotechnology to replace invalidated DA EO 8. After extensive consultation, it issued the DOST-DA-DENR-DOH-DILG Joint Department Circular No. 1, series of 2016. The new Circular seeks to address the findings of the Supreme Court for lack of meaningful participation. In this regard, the NCBP decided to expand membership of STRP, to require community representation in Institutional Biosafety Committee (IBC), to post in the Website and in Offices of all applications and their status, to require public hearing and LGU endorsement for field trial and commercial propagation. Likewise, any stakeholders and not just the applicant may appeal adverse decision of the NCBP and to address the absence of standards for risk assessment, NCBP decided to adopt the standard set by the Supreme which is reasonable certainty of no harm. (NCBP, 2016). 
With Joint Department Circular No 1 in hand, a Motion for Reconsideration (MR) was filed by GMO advocates. The SC then reversed its 2015 decision because the invalidated DAO 08-2002 was already superseded by new Circular. Thus, the temporary injunction against the field testing of GMOs especially Bt talong or eggplant no longer has basis (Maglungsod, 2016).

Figure 12

Institutional Experiences Versus Program Consequences

\begin{tabular}{|c|c|c|}
\hline Institutional Experiences & Year & Program Consequences \\
\hline $\begin{array}{l}\text { Pres. Corazon Aquino issued EO } 430 \text { creating } \\
\text { NCBP (Peczon, 2009) }\end{array}$ & 1990 & \\
\hline $\begin{array}{l}\text { Pres. Fidel Ramos approved the Five-Year Crop } \\
\text { Biotechnology Program and enact Agriculture and } \\
\text { Fisheries Modernization Act (AFMA) }\end{array}$ & 1997 & \\
\hline Adoption the Cartagena Protocol on Biosafety & 2000 & \\
\hline $\begin{array}{l}\text { Pres. Gloria Arroyo issued National Statement on } \\
\text { Modern Biotechnology (Peczon, 2009) }\end{array}$ & 2001 & $\begin{array}{l}\text { Protesters destroyed an going field trial on } \\
\text { Bt Corn in South Cotabato (Peczon, 2009) }\end{array}$ \\
\hline \multirow[t]{3}{*}{$\begin{array}{l}\text { DA issued EO } 8 \text { to regulate importation and } \\
\text { release of GMO (Peczon, 2009) } \\
\text { Commercial planting of Bt corn was approved by } \\
\text { DA (Peczon, 2009) }\end{array}$} & 2002 & \\
\hline & 2003 & $\begin{array}{l}\text { A petition was submitted to provincial } \\
\text { health officer of South Cotabato on } \\
\text { extraordinary experiences of residents } \\
\text { regarding their health which was } \\
\text { publicized by media (Peczon, 2009) } \\
\text { A Norwegian researcher conducted blood } \\
\text { sampling of } 38 \text { farmers in South Cotabato } \\
\text { (Peczon, 2009) }\end{array}$ \\
\hline & 2004 & $\begin{array}{l}\text { Norwegian researcher presented his } \\
\text { findings during the } 7^{\text {th }} \text { Convention on } \\
\text { Biological Diversity held in Bangkok } \\
\text { (Peczon, 2009) }\end{array}$ \\
\hline $\begin{array}{l}\text { Commercial planting of corn with tolerance to } \\
\text { herbicide glyphosate was approved by DA } \\
\text { (Peczon, 2009) }\end{array}$ & 2005 & \\
\hline $\begin{array}{l}\text { Ratification of the Cartagena Protocol on Biosafety } \\
(\mathrm{CPB}) \text { by Senate of the Philippines }\end{array}$ & 2006 & \\
\hline $\begin{array}{l}\text { Philippine National Biotechnology Week (NBW) } \\
\text { was created by Presidential Proclamation No. } 1414\end{array}$ & 2007 & \\
\hline $\begin{array}{l}\text { Philippines launched its National Biosafety } \\
\text { Clearinghouse, BCH Pilipinas, (Peczon, 2009) }\end{array}$ & 2008 & \\
\hline $\begin{array}{l}\text { Field Trial of Bt Cotton by Philippine Fiber } \\
\text { Development Administration (PFIDA) (ISAAA } \\
\text { Brief, 2016) }\end{array}$ & 2010 & $\begin{array}{l}\text { Mayor Sara Duterte-Carpio ordered the } \\
\text { uprooting of Bt eggplant being field-tested } \\
\text { at the UP Mindanao (Carillo and Padillo, } \\
\text { 2015). }\end{array}$ \\
\hline
\end{tabular}




\begin{tabular}{|l|l|l|l|}
\hline $\begin{array}{l}\text { Field trials of Bt Talong and Biotech Papaya by } \\
\text { Institute of Plant Breeding of the University of the } \\
\text { Philippines at Los Baños (IPB-UPLB) (ISAAA brief, } \\
\text { 2016) }\end{array}$ & 2012 & $\begin{array}{l}\text { A lawsuit was filed to halt the } \\
\text { commercialization of Bt eggplant. (ISAAA } \\
\text { Brief, 2016) }\end{array}$ \\
\hline $\begin{array}{l}\text { Confined Field Testing of Golden Rice by IRRI } \\
\text { (ISAAA Brief, 2016) }\end{array}$ & 2015 & $\begin{array}{l}\text { SC permanently stopped field testing of Bt } \\
\text { meter field trial plot of Golden Rice in Pili, } \\
\text { Camarines Sur (Berlekamp, 2013) } \\
\text { eggplant and declared DA-AO 8 null and } \\
\text { void. }\end{array}$ \\
\hline $\begin{array}{l}\text { Joint Department Circular (JDC) No. 1 was issued } \\
\text { by DOST-DA-DENR-DOH-DILG (ISAAA Brief, } \\
\text { 2016) }\end{array}$ & 2016 & $\begin{array}{l}\text { SC reversed its 2015 decision which } \\
\text { effectively halted the field testing, } \\
\text { propagation, commercialization, and } \\
\text { importation of GE products in the country. } \\
\text { (ISAAA Brief, 2016) }\end{array}$ \\
\hline $\begin{array}{l}\text { The Fertilizer and Pesticide Authority (FPA) issued } \\
\text { Memorandum Circular No. 10 (MC 10) or } \\
\text { “Guidelines for the Registration of Plant- } \\
\text { Incorporated Protectants (PIPs) in Pest-Protected } \\
\begin{array}{l}\text { Plants (PPP) and other Agricultural Pesticidal } \\
\text { Substances Derived from Modern Biotechnology }\end{array}\end{array}$ \\
\hline
\end{tabular}

With this SC decision, the government is allowed to resume the process of deregulating Bt talong eggplant and other GMOs (Conrow, 2016). Likewise, the Circular empowered the Fertilizer and Pesticide Authority (FPA) to regulate transformation event that has agricultural pesticide action which serves as Plant-Incorporated Protectant (PIP) in PestProtected Plant (PPP) produced through modern biotechnology. Figure 12 summarizes the institutional experiences and consequences of the programs promoting GM crops.

\section{Challenges of Biosafety Regulation}

In the process of implementing the biosafety regulation of the GM crops, there are challenges and consequences. Key informant interviews of different stakeholders revealed the following:

1. Costs of Greenhouse Testing. The current policy is that a GM crop has to undergo greenhouse trial before it is allowed to be field tested. This required greenhouse testing will have a large impact on costs especially to the applicants.

2. Difficult and Long Application Process. This is the cause of delay for the approval of applications, experiments, field trials and eventually commercialization of GM products. The NCBP biosafety application form contains questions which requires references from scientific literature. 
3. Difficulty of Collaboration between NCBP Members. The members of the NCBP have primary positions in government and private institutions and serves in parttime capacity. This nature of their appointments limits the frequency of their meetings to evaluate biosafety proposals due to difficulty of finding a common time among the members. In the United States, Australia and New Zealand, members are serving in full-time capacity (Mendoza et al, 2009).

4. Lack of IBCs Capacity on Decision Making. It has been observed that some of the IBCs cannot decided upon at their level and have to endorse every issues to the NCBP. There have been reports on the lack of commitment or knowledge on their responsibilities of some IBC members which had caused attendant delay on the approval of biosafety proposals (Mendoza et al, 2009).

5. Clashes with anti-GMO groups. Bringing GMO products to the market is difficult because of stringent biosafety regulations plus the fact that some NGOs are campaigning against GM crops. This leads to several hindrances such as numerous dialogues and confrontations with government regulators, scientists and technology developers, LGUs, and NGOs before the GMO products finally reached the market.

6. Post Harvest Requirement. It is required that immediately after harvest, plant materials should be heat killed, plowed under or buried in pits in the site which is difficult to farmers if they have a wide area of plantation (Mendoza et al, 2009).

7. Problem of Public Dissemination. This is mandatory requirement for field release trials composed of three layers of dissemination scheme which are Public Consultation in areas where the field trials will be conducted, posting of Public Information Sheets (PIS) in the community where the field trial will be conducted, and publishing of PIS for 2 consecutive weeks in a daily newspaper of national circulation. This requirement is time consuming especially if the public is not cooperative, or if the public is already indoctrinated by the anti-GMO groups.

8. Security Problems in Maintaining Field Sites. One requirement for the field trials is that the site should be secured against stray animals and unauthorized entry. But even with fences and guards, there were cases when plants were still uprooted and destroyed. Thus, maintaining security is very costly to the farmers. 
9. Strong Anti-GMO Campaign. This is one of the main problems members of the NCBP is facing at present. The simultaneous conduct by the anti-GMO advocates for a strong campaign against GMO was the reasons of the delay of field testing of Bt eggplant in the past. Their campaign usually resulted to summons to attend congressional investigations.

\section{Conclusions}

The Philippine experience in approving GM crops for commercialization took almost 16 years, that is from 2001 when field trials were done in South Cotabato, up to 2016 when the SC finally allowed GMO introduction in the country. One can say that the experience was a turbulent one, where every move of government was matched with violent reactions such as destruction of property, uprooting of GM crops, media black propaganda, lightning rally, a noise barrage, burning of a giant paper mâché bug, a religious crusade and hunger strike, among others. When all these have precipitated, anti-GMO groups hatched a long legal battle in court, lobbied or circulate petition for LGUs to enact ordinances banning entry of GMO, or persuade Congressmen to file a ban for GMO importation.

On the other hand, the government responds by launching a multi-media and multisectoral approach to public information campaign on biotechnology, or publication of magazines to feature recent developments in Philippine biotechnology to answers issues related to the technology. Aside from these, government offered course development and capability building to educate local officials. Members of NCBP also participate in Congressional hearings when summoned to explain the benefits of GMOs or go out in public to participate in a heated debate with anti-GMO groups.

Though lacking with biosafety rules, the Philippines attempted to start the field testing of Golden Rice in 1998 but it did not push since one of the necessary condition attached to the agreement with Golden Rice licensees is that no field releases may take place in the absence of a national regulatory framework. These events are bold steps in the middle of an era where other Asian countries are still groping in the dark on how to govern GMO debate, when other countries are likewise reconstructing biosafety regulatory mechanisms, or conducting researches, or tightly dealing with black propaganda of media outfits that focused more on uncertainties rather than the benefits the technology offers. 
From these experiences, regulators should learn that acceptance of this technology requires smooth and transparent communication process. The turbulent consequences was a result of insufficient public awareness and lack of understanding of what biotechnology is all about. Such brought uncontained fear which if proper intervention was initiated, violent resistance may have been neutralized. A well-informed media, and a dynamic collaboration among public and private sectors will prevent such scenario. In fact, this meaningful public participation, dialogue or public discourse was pointed out by the SC when it invalidates DAO 08-2002. The discreet act of the government in conducting field trials or commercial propagation of GM crops ( e.g Bt corn and Golden Rice), before making the project public provoked violent public resistance and long legal battle. Aside from mere posting and publication of notices and information sheets, a wider public participation means an agreement or consensus should be reached between two clashing of interests. The long legal battle as in the case of Bt talong, is due to the lack of clear understanding on the benefit and risk of biotechnology.

The Philippine experience suggest that a successful biosafety regulations have the following components: the regulatory policies should be science-based, presence of a flexible and transparent guidelines, a just procedures that cater to all stakeholder, a consistent biosafety review processes for regular monitoring of risk, an effective feedback mechanisms for monitoring, a smooth communication and awareness, a strong political support and a vigilant scientific community. Truly, GMO has an enormous impact to the food security program of the country because it addresses the many problems of a failed agriculture and has a high potential to fight poverty, hunger, and malnutrition vis-a-vis economic benefit to farmers due to increased yield.

While there are laws such as the Food, Drug, and Cosmetic Act (RA 3720) and the Customer Act which protects the public from hazardous food, drug, cosmetics and other commodities, there is still no Philippines law that touched biosafety regulations of GMOs. Thus, Congress should immediately enact a law this is becoming a worldwide governance concern. There are many pending bills in Congress which are not acted upon because the legislators either do not know the importance of the bill or are not interested in modernizing agriculture practices. And it is worth mentioning that these bills are in conflict with the biotechnology program of the national government to promote GM crops as they either ban 
entry, or penalize importation and introduction of GM crops. Likewise, there seems to be contradicting claims between the Philippine Food and Drug Administration (FDA) when it issued a statement attesting to the safety of GE and GE derived foods, while on the other hand pending bills are requesting mandatory labeling of GM foods.

The government should likewise provide the public with a national road map for the adoption of modern biotechnology to enlighten the public on the perceived outcome of this technology. Below is an example of a roadmap which will give the public a bird's eye view on the government's ultimate goal to promote this technology.

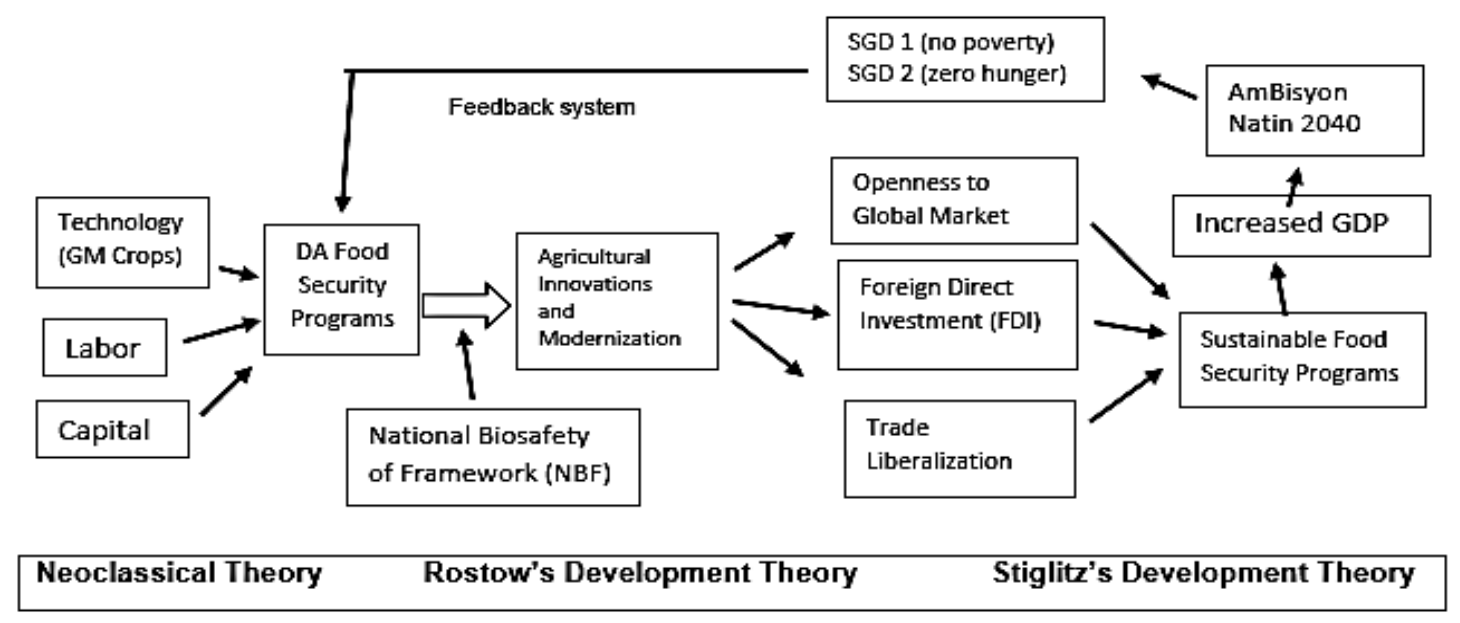

The national roadmap is anchored on the neoclassical theory which states that the drivers of the economic development are the right amount of capital, labor and technology, which in this case is the GM crop technology. With the proper biosafety measures of the NCBP, modern biotechnology will transform the country's food security program into innovations and modernization of the agricultural sector which will allow the Philippines to take off into a higher stage of development according to Rostow's Development Theory. Thus, removing protective laws (tariff, quota and other importation taxes) on GM seeds and goods will allow free flow of GM goods to the country and promote exchange of information. This is accordance with the Development Paradigm of Joseph Stiglitz (1998), openness to global market will give the country a comparative advantage because building relations highly developed countries will always result in learning, lessons which can be applied to the Philippine domestic market. Eventually, this will lead us to a sustainable food security program, an increase of Gross Domestic Product (GDP) and consequently realize AmBisyon Natin 2040 and Sustainable Development on the eradication of poverty and hunger. 


\section{References}

Alexandratos, N.B.J. World Agriculture Towards 2030/2050. (2012). Retrieved from www.faoorg/economic/esa.

Arueloi, L. (2017). Philippines GMO-Free Zones: Successful Roots in Organic Policy and Law. Retrieved from https://www.gmo-free-regions.org/fileadmin/files/gmo-freeregions/Philippines/The_Philippines_GMO-Free_Zones.pdf

Baulcombe, D.; Jones, J; Pickett, J; Puigdomenech, J. (2014). GM Science Update: A Report to the Council for Science and Technology. Retrieved from https://wwwgovuk/government/uploads/system/uploads/attachment data/ file/292174/cst-14-634a-gm-science-updatepdf.

Bawa, A.S.; Anilakumar, K.R.(2013). Genetically modified foods: safety risks and public concerns-a review, J. Food Sci. Technol. 50 (6) 1035-1046.

Berlekamp, L. (2013). Farmers Destroy 'Golden Rice' GMO Trials in Philippines. EcoWatch. Retrieved from https://www.ecowatch.com/beer-gluten-free-2640808623.html

CA Decision. (2013). Republic of Philippines Court of Appeal Manila. Special thirteenth division - notice of decision. Petitioners versus respondents. Retrieved from http://www.greenpeace.org/seasia/ph/PageFiles/126313/ca-decision-doc.pdf

Carillo, C and Padillo, M. (2015). CAO, green groups eye ban on GMOs in Davao. Business $\begin{array}{lll}\text { World } & \text { Online. } & \text { Retrieved }\end{array}$ http://www.bworldonline.com/content.php?section=Agribusiness\&title=cao-greengroups-eye-ban-on-gmos-in-davao\&id=115412

Conrow, J. (2016). Philippines Supreme Court reverses GMO ruling. Retrieved from https://allianceforscience.cornell.edu/blog/2016/07/philippines-supreme-courtreverses-gmo-ruling/

Crismundo, K. (2015). DA cites serious implications of banning genetically modified products. Philippines Today, Home of the Global Filipino. Retrieved from https://www.philippinestoday.net/archives/27034

Dubock, A. (2014). The politics of Golden Rice. Retrieved from https://doi.org/10.4161/21645698.2014.967570 
Espina, N (2006). Provincial offices, NGOs endorse GMO Free Zones. INQ7.net (Philippines). $\quad$ Retrieved from http://newsinfo.inq7.net/breakingnews/metroregions/view_article.php?article_id=980 0

Gilbert N. (2013), A hard look at GM crops, Nature 497 (7447) 24-26.

Glowka, L.,

(2002). The Role of Law in Realising the Potential and Avoiding the Risks of Modern Biotechnology, Commission on Genetic Resources for Food and Agriculture, Backgro und Study Paper No. 19.

GRAIN, MASIPAG and Stop Golden Rice! Network. (2018). Don't get fooled again! Unmasking two decades of lies about Golden Rice. Retrieved from https://www.grain.org/en/article/6067-don-t-get-fooled-again-unmasking-twodecades-of-lies-about-golden-rice

Gupta, A, (2000), “Governing Trade in Genetically Modified Organisms: The Cartagena Prot ocol on Biosafety", Environment, Vol.42, p. 22-23.

Gupta, A., (2001), “Ensuring "Safe Use” of Biotechnology in India: Key Challenges", Globali sation and Poverty Series.

IRRI (2016). There have been reports that Golden Rice field trials resulted in stunted plants and reduced grain yield. Is this true? Retrieved from http://irri.org/goldenrice/faqs/there-have-been-reports-that-golden-rice-field-trials-resulted-in-stuntedplants-and-reduced-grain-yield-is-this-true

ISAAA. (2014). Pocket $\mathrm{K}$ No. 48: Bt Eggplant. Retrieved from https://www.isaaa.org/resources/publications/pocketk/48/default.asp

James, C. (2013). Global Status of Commercialized Biotech/GM Crops, ISAAA Brief No. 46, 2013.

Maglungsod, B. (2016). SC reverses 2015 ruling vs GMO field trials. SEAMEO SEARCA Biotechnology Information Center. Retrieved from http://www.bic.searca.org/news/2016/jul/phil/27c.html

Mendoza EM, Garcia R, Sahagun M, Laurena A. (2009). Report for the National Committee on Biosafety of the Philippines (NCBP). Biosafety Regulations in the Philippines: A Review of the First Fifteen Years, Preparing for the Next Fifteen Years. 
NCBP.(2016). Joint Administrative Circular on GM Plant and Plant Products: Approaches to drafting the new regulation. Retrieved from file://C:/Users/Asus/Downloads/JACGMO-VizMin-ppt-25Jan16.pdf

Novenario, G. (2018). How Negros paved the way for organic agriculture. F\&B Report. Retrieved from http://fnbreport.ph/features/agriculture/how-negros-paved-the-wayfor-organic-agriculture-gabyn-20180511/

Philippines News Agency. (2015). North Cotabato bans GMO rice varieties. Business Mirror. Retrieved from https://businessmirror.com.ph/2015/11/04/north-cotabato-bans-gmorice-varieties/

Peczon, B. (2009). National Biotechnology Policies and Realism: Overcoming Challenges in Implementation. Research and Information System for Developing Countries (RIS). Asian Biotechnology and Development Review Vol. 11 No. 2, pp 45-53

Perez, AS. (2017). PH is top grower of GM crops in SEA. SunStar Philippines. Retrieved from https://www.sunstar.com.ph/article/143054

Raman, R. (2017) The impact of Genetically Modified (GM) crops in modern agriculture: A review, GM Crops \& Food, 8:4, 195-208, DOI: 10.1080/21645698.2017.1413522

Sharma, D., (2001), “The Introduction of Transgenic Cotton in India”, Biotechnology and De velopment Monitor, No. 44, p. 10-13.

Tansey, G., (2002), Food Security, Biotechnology and Intellectual Property: Unpacking Some Issues Around TRIPs, Quaker United Nations Office, Geneva.

Zhang, C; Wohlhueter, R; Zhang, H. (2016). Genetically modified foods: A critical review of their promise and problems. ScienceDirect. Food Science and Human Wellness 5 (2016) 116-123

2015 SC Decision: International Service for the Acquisition of Agri-Biotech Applications, Inc. Vs. Greenpeace Southeast Asia (Philippines), et al./Environmental Management Bureau of the Department of the Environment and Natural Resources Vs. Court of Appeals, et al./University of the Philippines Los Baños Foundation, Inc. Vs. Greenpeace Southeast Asia (Philippines), et al./University of the Philippines Vs. Greenpeace Southeast Asia (Philippines), et al. G.R. Nos. 209271, 209276, 209301, \& 209430, En Banc Decision penned by Associate Justice Martin S. Villarama, Jr., December 8, 2015. 